\title{
Society's Aggression Level as a Predictor of Traffic Fatality Rate
}

\author{
Michael Sivak
}

\begin{abstract}
This research investigated the relationship of violence/aggression and other societal variables to traffic accidents. In the first of two studies, multiple regression was applied to 1977 data from each of the 50 states and the District of Columbia. Traffic fatalities per registered vehicle was the dependent variable. The independent variables were homicide rate, suicide rate, fatality rate from other causes, unemployment rate, personal income, density of physicians, alcohol consumption, motor vehicles per capita, road mileage per vehicle, sex and age distribution of drivers, and attained education. The main finding was that the homicide rate (but not the suicide rate) predicted the traffic fatality rate; additional significant predictors were the proportion of young drivers and the fatality rate from non-motor-vehicle accidents. The two primary predictors (homicides and young drivers) accounted for $64 \%$ of the variance of traffic fatalities. In the second study, validation was performed by using the 1977 regression coefficients to estimate 1978 traffic fatalities. The results indicate that when the 1977 regression coefficients were applied to the 1978 values for homicides and young drivers, they accounted for $49 \%$ of the variance of the 1978 traffic fatalities. The findings are discussed in terms of how society's violence/aggression may contribute to traffic accidents.
\end{abstract}

The relationship between traffic fatalities and measures of aggression and violence has interested researchers for some time. For example, Porterfield (1960) and Whitlock (1971) have shown strong positive correlations between homicide/suicide rates in a given region (e.g., metropolitan areas, U.S. states, countries) and the corresponding motor vehicle fatalities. On the basis of such results, Whitlock concluded that "road-death and injury rates are the results, to a consider-

Michael Sivak, Ph.D., is an Associate Research Scientist at the University of Michigan Transportation Research Institute, Ann Arbor, Michigan. able extent, of the expression of aggressive behavior" (p. 104), and that "those societies with [the] greatest amount of violence and aggression in their structure will show this by externalizing some of this violence in the form of dangerous and aggressive driving with corresponding high casualty and accident rates" (p. 104). This provocative conclusion, however, was based on evidence derived only from correlational studies. Correlational analyses have a major limitation in the present context. They cannot control for effects of other variables (e.g., age, income, unemployment) that could contribute to a correlation between homicides/suicides and 
traffic fatalities. To control for the effects of other potentially significant variables, multivariate statistical techniques such as multiple regression have to be used. (See, e.g., Recht, 1965.)

The present research was designed to investigate the separate and joint effects of a range of variables, including homicide and suicide rates, on traffic fatalities. The basic units of analysis were each of the 50 states and the District of Columbia. Multiple regression was the primary analytical method used.

Two studies were performed. In the first, the values of the dependent and independent variables for the same year (1977) were entered in a multiple regression. In the second, regression coefficients (beta weights) of significant predictors of traffic fatalities for 1977 were used in estimating the traffic fatalities for the following year.

STUDY 1: MULTIPLE REGRESSION

OF THE 1977 DATA

\section{Method}

First, cross-correlations of all variables were performed. Second, multiple regression of the traffic fatalities on all independent variables was conducted.

Dependent variable. Traffic fatalities per registered vehicle (TRAFFAT) was the dependent variable. The value for each state was obtained by dividing the number of motor-vehicle-accident (traffic) fatalities in 1977 (National Center for Health Statistics, 1980) by the number of registered vehicles in 1977 (U.S. Department of Transportation, 1978).

Independent variables. The independent variables, data sources, and respective applicable years are presented in Table 1 . The two primary variables (HOMICID, SUICIDE) were selected to provide indexes of aggression/violence and despondency climates, respectively. The additional variables, each potentially related to traffic fatalities, estimated general risk-taking (NTRAFAC), quality of health care (OTHERFA, PHYSICI), degree of motorization (MVEHPCA), traffic density (ROADPVE), age distribution of driv- ers (YOUNGDR, OLDDR), sex distribution of drivers (MALEDR), economic climate (UNEMPLO, INCOME), educational level (HIGHSCH), and alcohol consumption (BEER, DISTSPI, WINE).

\section{Results}

The correlation matrix for all variables is shown in Table 2. These results indicate that homicide and suicide rates were significantly correlated with traffic accident fatalities. Other variables that correlated significantly with traffic fatalities are: proportion of young drivers, fatalities from non-motor-vehicle accidents, density of physicians, income per capita, road mileage per vehicle, and nonaccidental fatalities. As is apparent from Table 2 , however, each variable that is correlated with traffic fatalities is also correlated with a range of other variables, some of which, in turn, are correlated with traffic fatalities. For example, while homicide and suicide rates are both correlated with traffic fatalities, they are also correlated with fatalities from non-motor-vehicle accidents. Consequently, as was argued above, fatalities from nonmotor-vehicle accidents could potentially explain the relationship between homicide/suicide rates and traffic fatalities.

To evaluate the individual contribution of the partially confounded independent variables to the variation of traffic fatalities, multiple regression analysis was performed on standardized variables (Kerlinger \& Pedhazur, 1973). This analysis tests whether each independent variable is a statistically significant predictor of the dependent variable when all other variables are held constant. The results (Table 3 ) show that, even after controlling for the effects of the other variables, the homicide rate contributes significantly to the prediction of traffic fatalities (beta weight $=.40 ; p<.01$ ). Two additional variables (proportion of young drivers and non-motor-vehicle accident fatalities) are also statistically significant predictors of traffic fatalities, while the remaining 13 variables (including suicide rate) are not.

The total set of 16 independent variables accounts for $79 \%$ of the variance in states' traffic fatalities (Table 3 ). In comparison, if only the three significant predictors (homicides, young drivers, and non-motor-vehicle 
TABLE 1

STUDY 1: INDEPENDENT VARIABLES, DATA SOURCES, AND APPLICABLE YEARS

\begin{tabular}{|c|c|c|c|}
\hline \multicolumn{2}{|r|}{ VARIABLE } & \multirow[b]{2}{*}{ SOURCE } & \multirow{2}{*}{$\begin{array}{l}\text { APPLICABLE } \\
\text { YEAR } \\
\end{array}$} \\
\hline Code & Description & & \\
\hline HOMICID & Homicides per capita & $\begin{array}{l}\text { Computed by dividing homicides (Na- } \\
\text { tional Center for Health Statistics, } 1980 \text { ) } \\
\text { by population (U.S. Bureau of the Cen- } \\
\text { sus, } 1979 \text { ) }\end{array}$ & 1977 \\
\hline SUICIDE & Suicides per capita & $\begin{array}{l}\text { Computed by dividing suicides (Na- } \\
\text { tional Center of Health Statistics, } 1980 \text { ) } \\
\text { by population (U.S. Bureau of the Cen- } \\
\text { sus, } 1979 \text { ) }\end{array}$ & 1977 \\
\hline NTRAFAC & $\begin{array}{l}\text { Fatalities per capita from } \\
\text { accidents other than those } \\
\text { related to the operation of } \\
\text { motor vehicles }\end{array}$ & $\begin{array}{l}\text { Computed by dividing non-motor- } \\
\text { vehicle accident fatalities (National } \\
\text { Center for Health Statistics, } 1980 \text { ) by } \\
\text { population (U.S. Bureau of the Census, } \\
1979 \text { ) }\end{array}$ & 1977 \\
\hline OTHERFA & $\begin{array}{l}\text { Fatalities due to causes } \\
\text { other than accidents (traf- } \\
\text { fic or non-traffic), homi- } \\
\text { cides, and suicides }\end{array}$ & $\begin{array}{l}\text { Computed by dividing fatalities due } \\
\text { to causes other than the above (Na- } \\
\text { tional Center for Health Statistics, 1980) } \\
\text { by population (U.S. Bureau of the Cen- } \\
\text { sus, 1979) }\end{array}$ & 1977 \\
\hline PHYSICI & Physicians per capita & U.S. Burcau of the Census (1979) & 1977 \\
\hline MVEHPCA & Motor vehicles per capita & $\begin{array}{l}\text { Computed by dividing registered vehi- } \\
\text { cles (U.S. Department of Transportation, } \\
1978 \text { ) by population (U.S. Bureau of the } \\
\text { Census, } 1979 \text { ) }\end{array}$ & 1977 \\
\hline ROADPVE & Road mileage per vehicle & $\begin{array}{l}\text { Computed by dividing road mileage } \\
\text { (U.S. Bureau of the Census, 1979) by } \\
\text { registered vehicles (U.S. Department of } \\
\text { Transportation, 1978) }\end{array}$ & 1977 \\
\hline YOUNGDR & $\begin{array}{l}\text { Proportion of young } \\
\text { drivers ( } 24 \text { and under) }\end{array}$ & $\begin{array}{l}\text { U.S. Department of Transportation } \\
(\mathbf{1 9 7 8 )}\end{array}$ & 1977 \\
\hline OLDDR & $\begin{array}{l}\text { Proportion of old drivers } \\
\text { (65 and over) }\end{array}$ & $\begin{array}{l}\text { U.S. Department of Transportation } \\
(1978,1979,1980)\end{array}$ & $1977^{a}$ \\
\hline MALEDR & Proportion of male drivers & $\begin{array}{l}\text { U.S. Department of Transportation } \\
(1978)\end{array}$ & 1977 \\
\hline UNEMPLO & $\begin{array}{l}\text { Unemployment rate of } \\
\text { civilian labor force }\end{array}$ & U.S. Bureau of the Census (1978) & 1977 \\
\hline INCOME & Income per capita & U.S. Bureau of the Census (1978) & 1977 \\
\hline HIGHSCH & $\begin{array}{l}\text { Proportion of high school } \\
\text { graduates (persons } 18 \text { and } \\
\text { over) }\end{array}$ & U.S. Bureau of the Census (1978) & 1976 \\
\hline BEER & $\begin{array}{l}\text { Consumption of beer per } \\
\text { capita }\end{array}$ & U.S. Brewers Association (1978) & 1977 \\
\hline DISTSPI & $\begin{array}{l}\text { Consumption of distilled } \\
\text { spirits per capita }\end{array}$ & U.S. Brewers Association (1978) & 1977 \\
\hline WINE & $\begin{array}{l}\text { Consumption of wine per } \\
\text { capita }\end{array}$ & U.S. Brewers Association (1978) & 1977 \\
\hline
\end{tabular}

aExcept Alabama 1979, Massachusetts 1979, Rhode Island 1978, Vermont 1979.

accidents) are entered into another multiple regression, variance accounted for is $68 \%$; and if only homicides and young drivers are entered, it is $64 \%$. Thus, homicides and young drivers account for the majority of the variance attributable to the total set of the 16 independent variables. The remaining 14 variables, whether they are statistically significant in the multiple regression (e.g., nonmotor-vehicle accidents) or not (e.g., proportion of older drivers), contribute only marginally to the variance accounted for. 


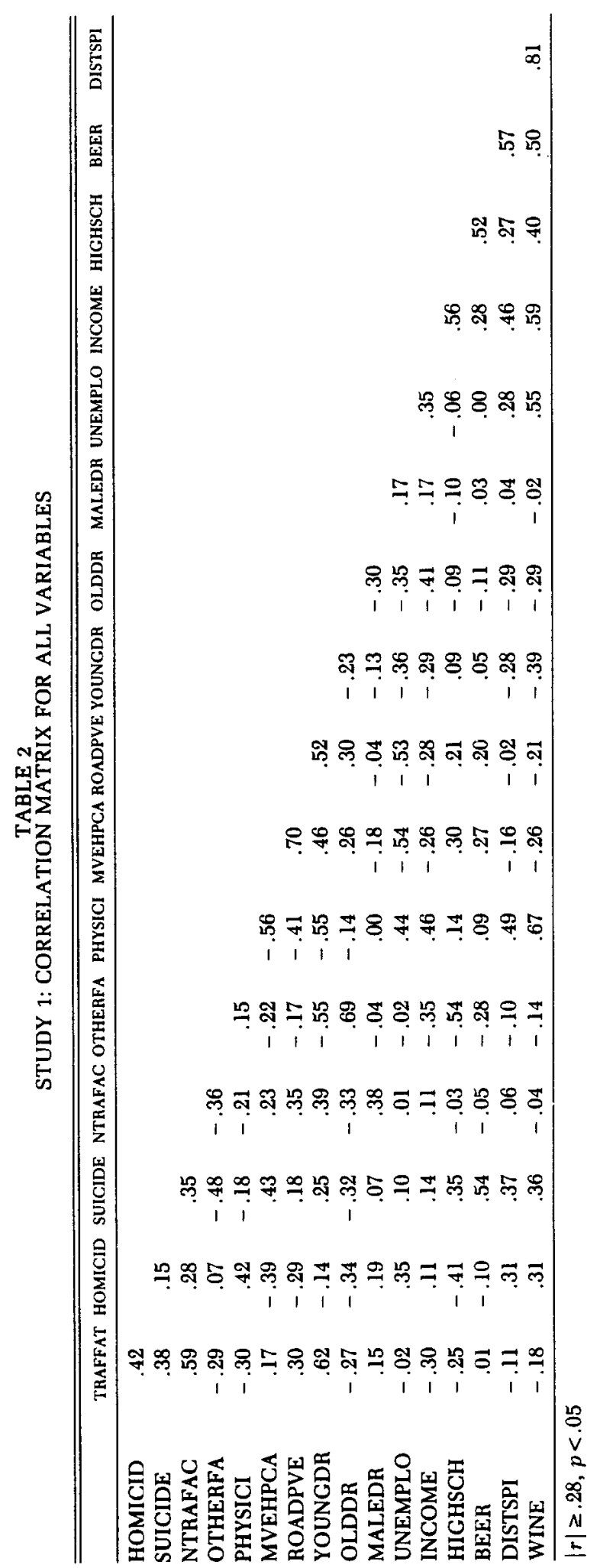


TABLE 3

STUDY 1: LEAST SQUARES REGRESSION OF TRAFFIC FATALITIES

\begin{tabular}{|c|c|c|c|}
\hline VARIABLE & $\begin{array}{c}\text { BETA } \\
\text { WEIGHT }\end{array}$ & $\begin{array}{l}\text { STANDARD } \\
\text { ERROR }\end{array}$ & $p$ \\
\hline HOMICID & .40 & .14 & $<.01$ \\
\hline SUICIDE & .25 & .16 & .13 \\
\hline NTRAFAC & .30 & .13 & .03 \\
\hline OTHERFA & .07 & .22 & .76 \\
\hline PHYSICI & -.03 & .17 & .87 \\
\hline MVEHPCA & -.27 & .17 & .11 \\
\hline ROADPVE & .18 & .18 & .31 \\
\hline YOUNGDR & .41 & .17 & .02 \\
\hline OLDDR & -.03 & .22 & .89 \\
\hline MALEDR & -.03 & .12 & .82 \\
\hline UNEMPLO & .08 & .13 & .55 \\
\hline INCOME & -.22 & .15 & .15 \\
\hline HIGHSCH & -.02 & .20 & .92 \\
\hline BEER & .20 & .13 & .13 \\
\hline DISTSPI & -.26 & .18 & .16 \\
\hline WINE & -.02 & .23 & .92 \\
\hline
\end{tabular}

$r^{2}=.79$

\section{Discussion}

Homicide rate. The correlational analysis indicates that homicide rate is significantly related to traffic fatalities. This finding is in agreement with previous correlational studies (Porterfield, 1960; Whitlock, 1971). Importantly, the multiple regression analysis implies that this relationship is not due to the effects of other potentially confounding variables. Even after controlling for the effects of 15 other variables, the homicide rate accounts for a significant amount of the variance of traffic fatalities. This result supports the notion of Whitlock (1971) that traffic accidents may be manifestations of aggression and violence in a society.

Suicide rate. The suicide rate is also significantly correlated with traffic fatalities. In contrast to the homicide rate, however, the suicide rate does not predict traffic fatalities if the effect of other independent variables is removed. This finding does not support a conclusion by Adams (1970), based on correlational findings, that the automobile is frequently employed "as an instrument of selfdestruction" (p. 10).
Driver age distribution. The proportion of young drivers is significantly correlated to traffic fatalities. Furthermore, it also predicts traffic fatalities even after controlling for the effects of a range of other variables. The implication is that young drivers, in general, create a more hazardous driving environment than older drivers. This is in agreement with the finding that young drivers have a higher accident rate per mile traveled than middleaged drivers (Planek, 1972). Since young drivers also accumulate a relatively high annual mileage (Planek, 1972), it is not surprising that they contribute to traffic fatality rates at the state level, as shown by the present study.

The proportion of older drivers, however, does not contribute significantly to traffic fatalities. Previous studies indicate that older drivers have a higher accident rate per mile traveled than middle-aged drivers (Planek, 1972). Since they accumulate relatively low annual mileage (Planek, 1972), however, they do not significantly affect traffic fatality rates at the state level.

The present data do not allow positive identification of underlying factors contributing to the strong effect of young drivers on traffic fatalities. Nevertheless, since aggression/violence and general risk-taking levels were controlled in the multiple regression, it is reasonable to speculate that lack of driving experience per se might be a contributing factor.

Non-motor-vehicle accidents. The correlational analysis indicates that the fatality rate from non-motor-vehicle accidents (e.g., falls, accidental poisonings, fires, etc.) is related to traffic fatalities. This relationship remains statistically significant even after controlling for the effects of 15 other variables, suggesting that general risk-taking is a significant factor in accident causation. This finding does not result from the tendency of young drivers to exhibit more risky driving behaviors (Hodgdon, Bragg, \& Finn, 1981), since the effect of the proportion of young drivers was controlled in the regression analysis. [While statistically significant in the regression analysis, the percentage of variance accounted for - in addition to the homicides and young drivers - is marginal (4\%).] 
Correlative but nonexplanatory variables. Several variables exhibit significant correlations with traffic fatalities but do not contribute significantly to the prediction of traffic fatalities when the effects of other variables are controlled. These variables are: (1) the above-discussed suicide rate; (2) fatalities resulting from causes other than accidents, homicides, or suicides; (3) density of physicians; (4) road mileage per vehicle; and (5) income per capita. This finding demonstrates the need to control for the effects of potentially confounding variables in accident-causation research. Relying only on correlational analysis, as many studies have done, can result in misleading interpretations.

STUDY 2: PREDICTION OF THE

1978 DATA USING THE 1977

REGRESSION COEFFICIENTS

\section{Method}

This study constituted a validation of the relationships obtained in the preceding 1977 multiple regression. First, the 1977 regression coefficients were used to predict the standardized 1978 traffic fatalities. Second, the correlation coefficient was computed for the predicted and actual standardized values of the 1978 traffic fatalities.

The predicted standardized values of the 1978 traffic fatalities were computed as follows:

$$
\left(\mathrm{S}_{\mathrm{H}, 1978}\right)\left(\mathrm{B}_{\mathrm{H}, 1977}\right)+\left(\mathrm{S}_{\mathrm{Y}, 1978}\right)\left(\mathrm{B}_{\mathrm{Y}, 1977}\right)
$$

where

$$
\begin{aligned}
& \mathrm{S}_{\mathrm{H}, 1978}=\text { standardized } 1978 \text { homicide } \\
& \mathrm{S}_{\mathrm{Y}, 1978}=\text { standardized } 1978 \text { proportions }
\end{aligned}
$$

The unstandardized 1978 homicide rates were obtained by dividing the 1978 homicides (National Center for Health Statistics, 1982 ) by the 1978 population (U.S. Bureau of Census, 1980) for each state. The unstandardized 1978 proportions of young drivers were taken from U.S. Department of Transportation statistics (1979).

The actual 1978 traffic fatality rate in each state was obtained by dividing the number of traffic fatalities in 1978 (National Center for Health Statistics, 1982) by the number of registered vehicles in 1978 (U.S. Department of Transportation, 1979).

\section{Results}

The product-moment correlation coefficient between the actual and predicted standardized 1978 traffic fatalities was $r=.70$. With 49 degrees of freedom, this correlation is highly significant $(p<.001)$. Furthermore, $49 \%\left(.70^{2}=.49\right)$ of the variance in the actual 1978 fatalities can be accounted for by knowing the 1978 values of the homicide rates and the proportions of young drivers, coupled with the corresponding beta weights from the 1977 multiple regression. In comparison, using the 1978 values of homicides and young drivers in a multiple regression (and thus finding the best-fitting 1978 regression coefficients) would account for $51 \%$ of the variance of the 1978 traffic fatalities.

\section{Discussion}

The results of this study indicate that the 1977 regression coefficients (when applied to the 1978 values for homicides and young drivers) can account for virtually as much variance of the 1978 traffic fatalities as can the best-fitting 1978 regression coefficients $(49 \%$ vs. $51 \%)$. While these results suggest that homicides and young drivers are good predictors of traffic fatalities, further validation is needed. Of particular interest would be validations for time periods further removed from the time period of the original multiple regression.

\section{CONCLUSIONS}

This investigation found statistically significant independent effects of the following three variables on traffic fatalities: homicide 
rate, proportion of young drivers, and nonmotor-vehicle accident fatality rate. These three factors account for $68 \%$ of the variance of the 1977 traffic fatalities for the 50 states and the District of Columbia.

The predictive power of the two primary factors (homicides and young drivers), which accounted for $64 \%$ of the variance, was validated by using the corresponding 1978 data and 1977 regression coefficients to predict the 1978 traffic fatality rates. In this analysis, the homicide rates and the proportion of young drivers accounted for $49 \%$ of the variance.

These findings suggest that: (1) society's level of violence and aggression affects the extent of aggressive driving and, consequently, the frequency of traffic accidents; and (2) young drivers are a significant factor in the traffic accident problem, probably because of their lack of experience.

\section{REFERENCES}

Adams, J. R. Personality variables associated with traffic accidents. Behavioral Research in Highway Safety, 1970, 1, 3-18.

Hodgdon, J. D., Bragg, B. W. E., \& Finn, P. Young driver risk-taking research: The state of the art (Interim Report No. 81-68). Cambridge, MA: ABT Associates, March 1981.

Kerlinger, F. N., \& Pedhazur, E. J. Multiple regression in behavioral research. New York: Holt, Rinehart and Winston, 1973.

National Center for Health Statistics. Vital statistics of the United States: 1977. Volume II, Part B. Washington, DC: U.S. Government Printing Office, 1980.

National Center for Health Statistics. Vital statistics of the United States: 1978. Volume II, Part B. Washington, DC: U.S. Government Printing Office, 1982.

Planek, T. W. The aging driver in today's traffic: A critical review. In P. F. Waller (Ed.), Aging and highway safety: The elderly in a mobile society, North Carolina Symposium on Highway Safety (Vol. 7). Chapel Hill, NC: The University of North Carolina Highway Safety Research Center, 1972.

Porterfield, A. L. Traffic fatalities, suicide, and homicide. American Sociological Review, 1960, 25, 897901 .

Recht, J. L. Multiple regression study of the effects of safety activities on the traffic accident problem. Chicago: National Safety Council, December 1965.

U.S. Brewers Association. Brewers almanac. The brewing industry in the United States. Washington, DC: Author, 1978.

U.S. Bureau of the Census. Statistical abstract of the United States: 1978 (99th ed.). Washington, DC: U.S. Government Printing Office, 1978.

U.S. Bureau of the Census. Statistical abstract of the United States: 1979 (100th ed.). Washington, DC: U.S. Government Printing Office, 1979.

U.S. Bureau of the Census. Statistical abstract of the United States: 1980 (101st ed.). Washington, DC: U.S. Government Printing Office, 1980.

U.S. Department of Transportation. Highway statistics: 1977. Washington, DC: U.S. Government Printing Office, 1978.

U.S. Department of Transportation. Highway statistics: 1978. Washington, DC: U.S. Government Printing Office, 1979.

U.S. Department of Transportation. Highway statistics: 1979. Washington, DC: U.S. Government Printing Office, 1980

Whitlock, F. A. Death on the road: A study in social violence. London: Tavistock, 1971. 